\title{
The Jewish farmer, the village and the world fair: politics, propaganda, and the "Israel in Palestine" pavilion at the Paris International Exhibition of 1937
}

\author{
Tzafrir Fainholtz ${ }^{1,1}$ \\ ${ }^{1}$ Technion, Israel institute of technology, Faculty of architecture and town planning, Haifa, Israel
}

\begin{abstract}
At the Paris International Exhibition of 1937, a few steps from the Nazi Germany and USSR pavilions the Yishuv (Palestine's Jewish Zionist community) had its own presence, the "Israel in Palestine" pavilion. Initiated by the Zionist leadership, the pavilion was a hybrid construct of modernist and traditional architecture; its front was made from concrete and glass, its rear modelled on Palestine's rural vernacular architecture, with arches and terraces. Inside the pavilion, the exhibition depicted the achievements of the Zionist Jewish resettlement project, presenting it as a solution for the so-called "Jewish question". Conceived as part of an orchestrated effort by the Zionist movement to use the World Fair, the professional architectural media, writers, and architects to gain support for the movement's activities, the pavilion sought to present Palestine's settler society as both modern and well rooted, and to display the renaissance of nationhood through the representation of the Jewish farmer on the international stage.
\end{abstract}

\section{Introduction}

L'Exposition internationale des arts et techniques dans la vie moderne, the Paris international Exhibition of 1937, was the biggest exhibition of its kind during the 1930s, and was visually dominated by the state pavilions of Nazi Germany, designed by Albert Speer, and of the USSR, designed by Boris Yofan. A few steps from the pavilion of the USSR, and opposite the pavilion of the Kingdom of Romania, stood the "Israel in Palestine" pavilion representing the Yishuv (Palestine's Jewish Zionist community) ${ }^{2}$. Preceding the establishment of the State of Israel in 1948, the pavilion was initiated by organizations affiliated with the Zionist movement, as an instrument for displaying the achievements of the Zionist Jewish resettlement project.

Designed as a hybrid of modernist and traditional architecture, the pavilion's front was a modernist structure of white concrete and glass, while its rear was modelled in the image of Palestine's rural vernacular architecture, reminiscent of the Arab villages

\footnotetext{
${ }^{1}$ Corresponding author: ftzafrir@gmail.com

${ }^{2}$ Exposition international de 1937, emplacement de la Palestine et de la Roumanie, plan, CZA (Central Zionist Archive, Jerusalem) L71 7-1m.
} 
of the region ${ }^{3}$. The exhibition inside the pavilion depicted the ongoing Zionist Jewish resettlement project in Palestine. The frieze enveloping the main hall of the pavilion depicted scenes of the rural life that would resolve the "Jewish question", the plight of the persecuted Jews, through the birth of a new society of farmers and manual labourers, manifestations of a new, advanced society.

An amalgam of "rational" architecture and oriental fantasy, the pavilion had been conceived as part of an orchestrated effort by the Zionist architectural and political milieu to disseminate and publicize the story of the Zionist movement's cooperative rural settlements, and especially the cooperative settlements of the Kibbutz and the Moshav, abroad. This endeavour incorporated the goodwill of international professional journals like the French L'Architecture d'Aujourd'hui, writers like Julius Posener, planners like Richard Kauffmann, and international architectural organization like the RIA (Réunions Internationales d'Architectes).

This paper presents how the World Fair, the architecture media, and international organizations were used by the Zionist establishment in the 1930s as a tool for promoting the idea of the rural resettlement of Palestine, at a period when the rise of antisemitism in Europe made the question of Jewish resettlement outside of the continent critical. It will discuss how the image of the rural settlement was broadcast as a depiction of social and national reform, how the Jewish farmer was put on display at the World Fair, and how the dichotomy between historical roots and modern reform was used at the Paris International Exhibition of 1937 to present the renaissance of the Jewish farmer as an answer to the "Jewish question".

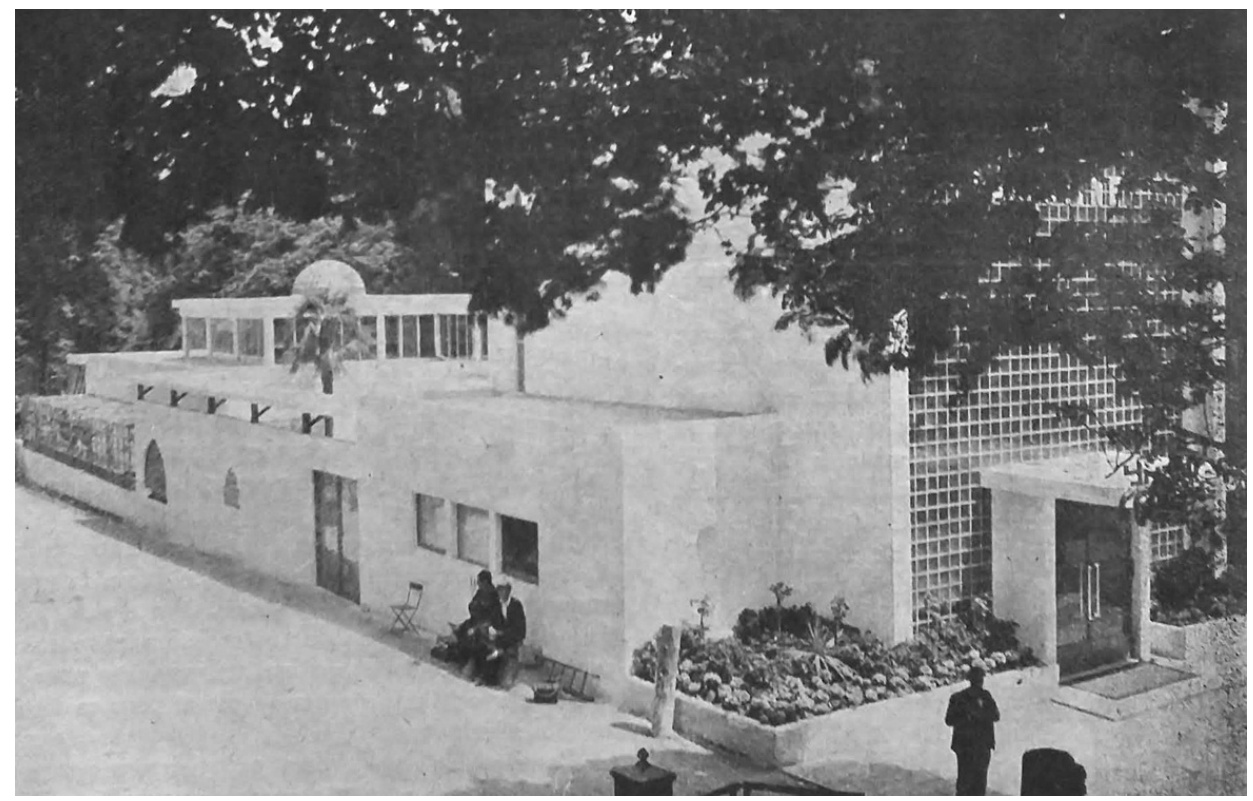

Fig. 1. The Israel in Palestine Pavilion. (Source: [1: 1]).

3 "Israel in Palestine" pavilion (1937). Photograph, CZA L71 1-21p.

"Israel in Palestine" pavilion (1937). Photograph, CZA L71\1-23p.

"Israel in Palestine" pavilion, model (n.d.). Photograph, CZA L71\1-24p.

4 "Israel in Palestine" pavilion, interior (n.d.). Photograph, CZA L71\1-22p.

"לפתיחת הביתן הא"י בתערוכת פריז" ["For the opening of the Palestine pavilion at the Paris exhibition] (1937). Manuscript, CZA L71\8, 120/58. 


\section{The farmer, the planner, the writer - publicizing the new Jewish village}

As early as the 1870s, the rebirth of Jewish nationhood in Palestine was closely aligned with the rebirth of the Jew, as a farmer and manual labourer ${ }^{5}$. By the end of the $19^{\text {th }}$ century, Zionist political ideology had framed the rural colonization of Palestine as a type of reform that would bring about the creation of a "New Jew" [2], as a natural man, a man living off the land. In support of this construct of the New Jew, two new models of rural settlements were created in the first decades of the $20^{\text {th }}$ century, the Kibbutz and the Moshav ${ }^{6}$.

By the 1920s, it had become clear that there was need for the involvement of professional players in the Zionist resettlement project. Arthur Ruppin ${ }^{7}$, head of the Zionist "Eretz Israel" office, invited the German-Jewish architect Richard Kauffmann ${ }^{8}$ to come to Palestine and serve as the de-facto head planner of the Zionist planning project. Kauffmann was a disciple of the "Garden city" movement; in the following years, he was to produce innovative models for the new rural Jewish colonies in Palestine, including the plans for the first moshav, Nahalal, in 1921, and for the first purpose-built "big" kibbutz, Ein Harod, in 1926 [5, 6]. In 1926, Kauffmann published accounts of his work in Palestine in the German magazine Städtebau, under the title "Judische Siedlungen in Palastina" [7], and in the British journal Town Planning Review under the title "Planning of Jewish Settlements in Palestine" [8]. These reports depicted his unique plans for Nahalal and other settlements in Palestine, conveying the novelty of the Zionist rural project to readers abroad.

Kauffmann was an architect, who promoted his work through writing; but by the 1930s, the Zionist resettlement project gained the services of a professional architectural journalist, following the arrival of the architect Julius Posener ${ }^{9}$ to Palestine. Posener, who would subsequently become one of Germany's leading architecture scholars, arrived to Palestine from Paris in 1935. A journalist since 1930, between 1934-1935 he was the editorial secretary of the highly influential French magazine L'Architecture d'Aujourd'hui ${ }^{10}$. In Palestine, Posener met architect Sam Barkai ${ }^{11}$, correspondent for L'Architecture d'Aujourd'hui in the country since 1934 [9]. Both men became members of Palestine's Chug Ha-Adrichalim (architects circle), a group of modernist architects who championed the development of modernist architecture in Palestine [10]. Posener and Barkai were both involved in the publication of the Chug's magazine, Habinyan, which was published (in only three issues) between 1937 and $1938^{12}$.

\footnotetext{
${ }^{5}$ The first Jewish colony, "Petah Tikva" was founded by Jews from Jerusalem in 1878; the first Agricultural school, "Mikve Israel", was founded in 1870.

6 The Kibbutz was a communal village; the first Kibbutz was a kvutza, a small rural commune, called Degania, which was founded in 1909-1910. The Moshav was a cooperative village; the first Moshav, Nahlal, was founded in 1921. For more about the Kibbutz and the Moshav see [3, 4]. 7 1876-1943, A Zionist leader, economist and sociologist, was head of the Eretz Israel (Palestine) Office.

8 1887-1958, Architect and urban planner.

${ }^{9}$ 1904-1996, Architectural historian and author.

${ }^{10}$ BLOC, A. 1948. "Lettre de certificat, Julius Posener", 15 October. ADK (Akademie der Künst, Berlin), Pos-01-521.

11 1898-1975, Architect and architectural journalist.

12 הבנין - עיתון לאדריכלות ולבנין ערים [Habinyan - Journal for Architecture and Town Planning]: $n^{\circ} 1$, August 1937; n², November 1937; n³, August 1938.
} 
In 1937, Posener and Barkai collaborated in the writing and production of a special and substantial segment of the September issue of L'Architecture d'Aujourd'hui. The issue, dedicated to the new modernist architecture and urban planning in Palestine, was entitled "Architecture in Palestine" [11]. An important part of Posener and Barkai's segment was dedicated to the Jewish rural settlements in Palestine, which they depicted as revolutionary, modern, brave and unique. Posener and Barkai did incorporate some photographs of Arab rural dwellings; these served to demonstrate the poverty of the rural dwellings of the Fellah (Arab Palestinian farmer), but at the same time emphasized the ancient ties of the Jewish rural project to the vernacular architecture of the country, and underlined the superior modern spirit of the Zionist movement ${ }^{13}$.

Posener's role in the publication of the Zionist planning and architecture journal abroad turned him into what he defined as a "writer". On $18^{\text {th }}$ March 1938, he wrote to Kauffmann, asking for photographs and plans of his work. These Posener planned to publish in six different international journals ${ }^{14}$. In the same year, he featured Kauffmann's work in his article, "Traditional and modem buildings in Palestine", published in the Swiss Journal Das Werk [13]. The importance which Posener and other Zionist planners placed in the publication of the Zionist planning project abroad led them to collaborate in the international organization RIA (Réunions Internationales d'Architectes), established by Pierre Vago and André Bloc, the editors of L'Architecture d'Aujourd'hui, in 1932 [14: §15]. The conferences were an opportunity for them to depict the novelty of the new settlements in Palestine. At the third RIA conference in 1935, in Prague [15], a paper by the architect Yohanan Ratner presented this innovation in contrast to the vernacular Arab villages writing: "Villages and collective farms, row of modern buildings, were planted in the empty spaces between the Arab villages on the hills; can there be a synthesis of these opposing aspects?" [16]. In 1938, Posener, Barkai and Nahum Salkind attempted to bring the RIA conference to Palestine ${ }^{15}$, but this did not come to pass.

Posener and Ratner's depiction of the Zionist settlement project detailed its modernist image, but also succeeded in depicting it in relation to the local traditions of Palestine's vernacular. This dichotomy was evident in the design of the "Eretz Israel" Pavilion at the 1937 World Fair, which was featured, in a short reportage of just a few pages, from the "Architecture in Palestine" segment of L'Architecture d'Aujourd'hui. This connection between the print media and the exhibition pavilion turned out to be less then coincidental: this issue of L'Architecture d'Aujourd'hui was distributed in the pavilion, evidence of the joint effort effected by the print media and the World Fair to present the image of the Jewish Farmer, and part of an effort which had its roots in the first decades of the Zionist movement.

\section{Exhibiting the Jewish Farmer - the village and the World Fair}

As early as the 1890s, the Zionist movement had begun to exhibit in international exhibitions, a way of gaining support for its cause. In the 1920s this activity became more professional, with the establishment of the "Trade and Industry" company in Tel Aviv. The company sought to encourage the economic development of the Yishuv

\footnotetext{
13 "Construction et plan d'une maison paysanne Arabe" [11: 19]. Some of the Images In the segment were taken from a book by Tawfiq Canaan [12]. Canaan was an Arab physician, and a known Palestinian nationalist, their inclusion in the publication must have happened without his authorization. ${ }^{14}$ POSENER, J. 1938. "Brief an Richard Kauffmann", 18 March. ADK (Akademie der Künst, Berlin) Pos-01-436.

${ }^{15}$ POSENER, J.; SALKIND, N.; BARKAI, S. 1937, Letter concerning the RIA conference. ADK (Akademie der Künst, Berlin) HZA-01-419.
} 
through print media and international exhibitions [17]. The flagship of "Trade and Industry" was an international exhibition, organized in Tel Aviv under the name "The Levant Fair". The first fair, modest in size, took place in 1924; but by 1934, the event had become an impressive enterprise, and a fairground area was built in the north of Tel Aviv to accommodate it, to the urban plan of Richard Kauffmann. Kauffmann was also responsible for the fair's central building, the "Tozeret HaAretz Palace" [18], a modernist pavilion in which Jewish Palestine achievements in agriculture and industry were celebrated. The symbol of the exhibition, known as the "Flying Camel", depicted the Zionist connection to Palestine's past and future. This winged camel was designed by the architect Arieh Elhanani (Spojnikov) ${ }^{16}$, who was Trade and Industry's exhibition designer. Elhanani also produced the exhibition's central work of art, a sculpture of the "Hebrew Worker", intended as a "constructivist" representation of the "New Jew".

Trade and Industry became the main producer for international exhibitions dedicated to the Zionist cause. In 1931, it produced the Palestine pavilion for the Paris colonial exhibition, the Exposition colonial international of 1931. The Eretz Israel Palestine pavilion was initiated by Trade and Industry, in collaboration with the Franco-Palestinian Chamber of Commerce [19]. The domed structure was a modern interpretation of Rachel's Tomb [20], an ancient Jewish sacred site in the city of Bethlehem ${ }^{17}$. The pavilion presented a modern twist to a previous Palestine pavilion, which had represented British Palestine at the "British Empire exhibition" in Wembley, London, in 1924, also an historicist middleeastern and domed building [22]. Inside the building, the planning of new cities and new forms of rural settlement in Palestine were depicted through panoramas and models of Zionist settlement in Palestine, and included a model of Kauffman's Nahalal ${ }^{18}$.

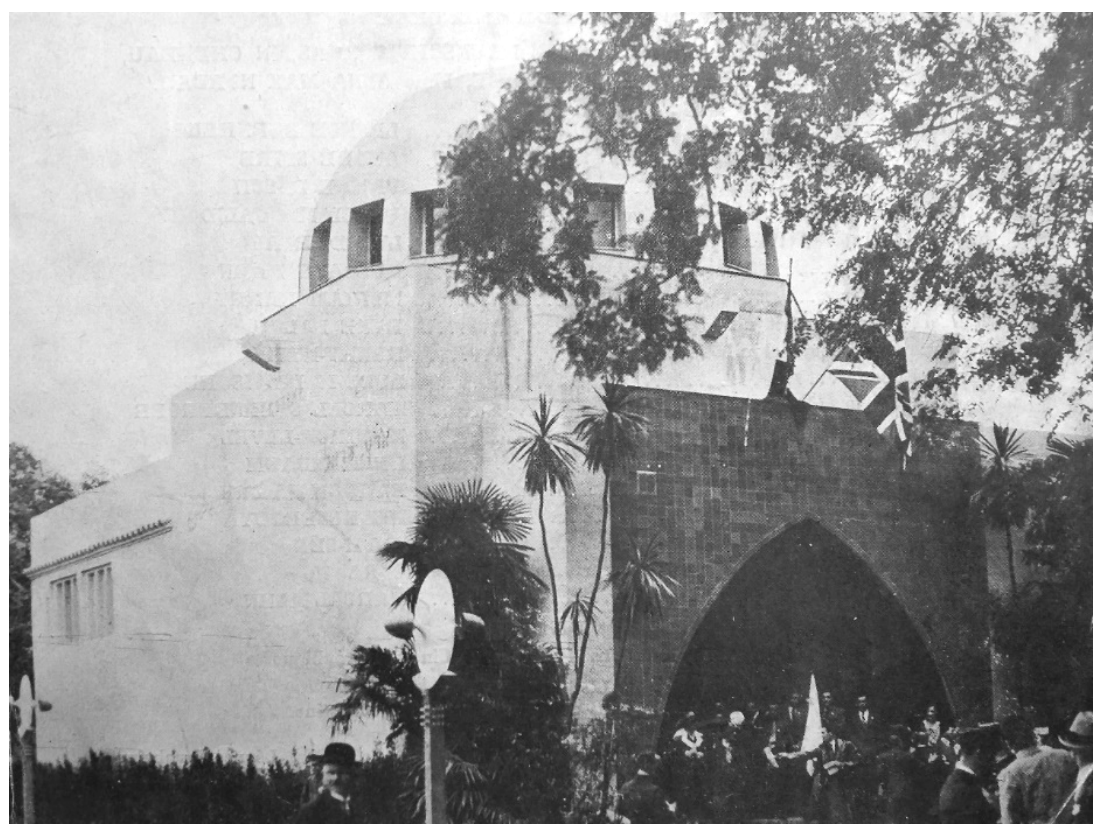

Fig. 2. The Palestine Pavillon. (Source: [23]).

\footnotetext{
${ }^{16}$ 1985-1898, Architect, stage designer and graphic artist.

${ }^{17}$ The Historicist building was not out of character with the eclectic architecture of the fair, for more about other buildings at the exhibition, see [21].

${ }^{18}$ Management of the "Palestine pavilion". Letter to the head office of Keren-HaYesod (1931) [Hebrew]. 17 March, CZA KKL5\4021.
} 
The exhibition was followed by an international conference, held between 10-15 October 1931 under the title "The international congress for urbanism in the colonies and countries in the intertropical latitudes"19. Hosted in the exhibition grounds in Paris, the conference was headed by Marechal Lyautey, director of the exhibition, with the involvement of the architects and urban planners Henry Prost and Jean Royer. The next year, all three collaborated in the publication of the magazine Urbanisme $e^{20}$. One of the British members of the conference's organizing committee, Fitz Herbert Ruxton, wrote to Dr. Chaim Weitzman, Head of the Jewish agency for Palestine and the future Israeli president, to inform him of the interest of the French members of the committee in the colonies in Palestine, and stressed the importance of sending a delegate to represent the Zionist movement in the conference in Paris. Weitzman approached Arthur Ruppin, who recommended that Richard Kauffmann should participate in the conference ${ }^{21}$. Kaufmann travelled to Paris, and presented a paper which, according the conference's "Note pour la presse" dealt with "the enormous effort of the contemporary initiative to create Zionist agricultural cities",22.

Kauffmann's paper was published in the conference's proceedings, Urbanism in the colonies and in the Tropical colonies, under the title: "The organizing of Jewish colonies in Palestine, especially the planning of agricultural colonies of the Zionist organization" [25]. In the paper, Kauffmann declared that the aim of Zionism was the rebirth of the Jewish people. He went on to present the exceptional nature of the new agricultural settlements in Palestine, writing: "We found ourselves, in the Land of Israel, faced with the need to create a completely new type of agricultural colony" for settlers, who "shared the deep idea that only spiritual rebirth will be able to activate the revival of the Jewish people" [25: 224].

The colonial exhibition took place only two years before Hitler's rise to power in Germany. Six years later, in 1937, L'Exposition internationale des arts et techniques dans la vie moderne would open in Paris. Opening in a politically strained atmosphere, it was described by Leon Blum (prime minister of France at the time) as the "last hope for peace in Europe" [26: 170]. In this dire period, just before the Holocaust, the Zionist movement conceived its pavilion not only to put the phenomenon of the Zionist farmer on display, but also to present him as the solution to the "Jewish Question", in light of the on-going persecution of the Jews of Europe.

\section{The Jewish Farmer and the "Jewish Question" at the Paris International Exhibition of 1937}

The Jewish Palestine Pavilion, the Pavillon d'Israel en Palestine, stood in the Trocadero area. It was another cooperation between Trade and Industry, the Franco-Palestine Chamber of Commerce, and other Zionist organizations ${ }^{23}$. The building was designed by two young and unknown architects, Tamir and Grinshpon, in collaboration with local

\footnotetext{
19 "Congrès international de l'urbanisme aux colonies et dans les pays de latitude intertropicale", for more about the content of the conference, see [24]; and the conference program: L'Urbanisme aux colonies et dans les pays tropicaux (n.d.). Conference program, CZA A175.98.

${ }^{20}$ For more information about the magazine, see: http://portaildocumentaire.citedelarchitecture.fr/nos-revues.aspx, [accessed 20.6.2018]

${ }^{21}$ According to correspondence kept in Kauffmann's archive, file CZA (Central Zionist Archive) A175.98

${ }_{22}$ Note pour la presse sur le congrès international d'urbanisme (n.d.). CZA A175.98.

${ }^{23}$ Correspondence of the organizers, kept at CZA L7113.
} 
architects Lopez, Merlet et Charpentier [27]. Entrance to the Pavilion was through a raised pavilion, with a modernist façade of glass panels. The pavilion encircled an inner courtyard, surrounded by the exhibition's wings; the rear of its entrance was adorned with a mural depicting Jewish farmers picking oranges ${ }^{24}$. The rear wings were styled in a mishmash of modernism and Oriental elements, including a pierced dome, pointed arches, pergolas, and a Palm tree ${ }^{25}$, the ancient symbol of Judea.

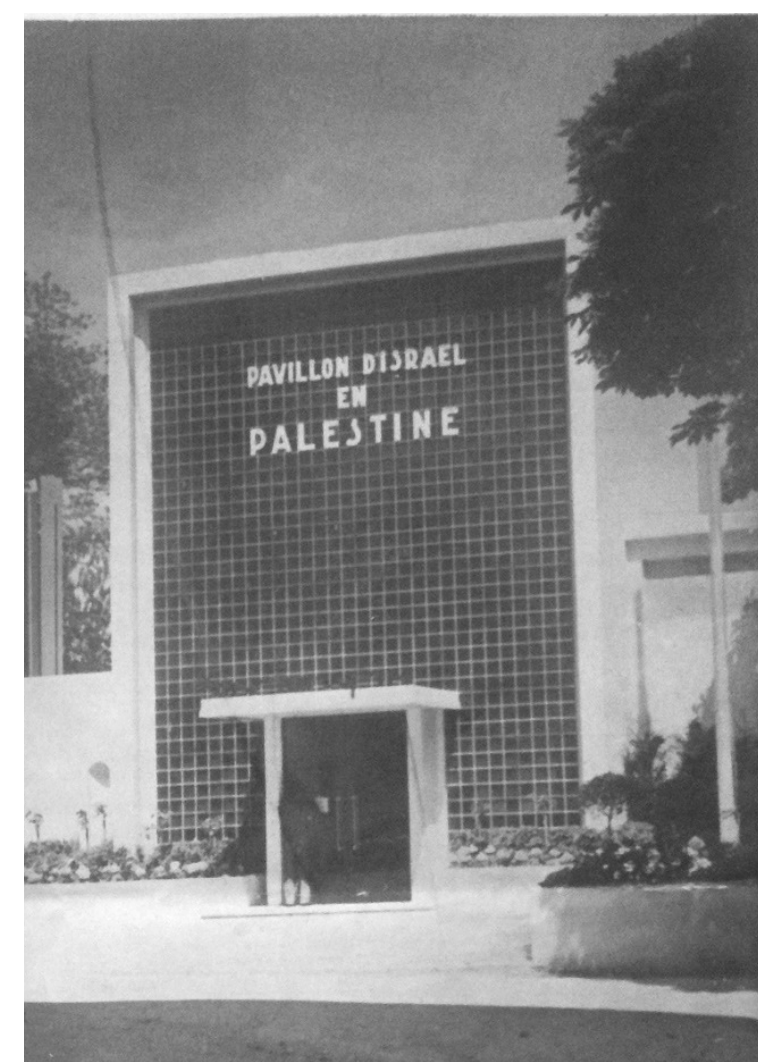

Fig. 3. Main Façade of The Israel in Palestine Pavilion. (Source: [28: 609]).

Inside the building, the exhibition presented the benefits of Jewish immigration to Palestine, depicting the arrival of the Jews fleeing Germany to the country as beneficial to the both the Jewish and Arab residents of the country. The exhibition halls displayed Zionist rural and industrial achievements, including the rural settlement enterprise, the port of Haifa, and the city of Tel Aviv. Arieh Elhanani, who designed the exhibition, accentuated the role of the Jewish farmer by exhibiting life-size cutouts of photographs showing Jews engaged in manual labour, driving tractors, cultivating the land, and working for Jewish immigration ${ }^{26}$. Encircling the main hall (the Rothschild Hall) was a quote attributed to Theodor Herzl, the "Father" of Zionism: "when the plough will be in the grip of the Jewish farmer, we will hold the solution for the Jewish question"27. The

\footnotetext{
24 "Israel in Palestine" pavilion (1937). Photograph, CZA L71\1-23p.

25 "Israel in Palestine" pavilion, model (n.d.). Photograph, CZA L71\1-24p.

26 "Israel in Palestine" pavilion (1937), interior. Photograph, CZA L71\1-22p.

27 " ["For the opening of the Palestine pavilion at the Paris exhibition] (1937). Manuscript, CZA L71\8, 120/58.
} 
exhibition in the hall was set in the form of panoramas in niches, displayed different aspects of farming. It ended with an image of a Jewish village in Palestine, showing a Jewish farmer telling his sons and grandsons the story of three generations of Jewish farming ${ }^{27}$. It portrayed the farmer as the "New Jew", and as a solution to the "Jewish Question". This message was not lost on the public: a journalist with Davar, a Hebrew newspaper, noted: "The pictures and photographs are showing the revolution that has occurred among the Jews: the Jew became a farmer" [29].

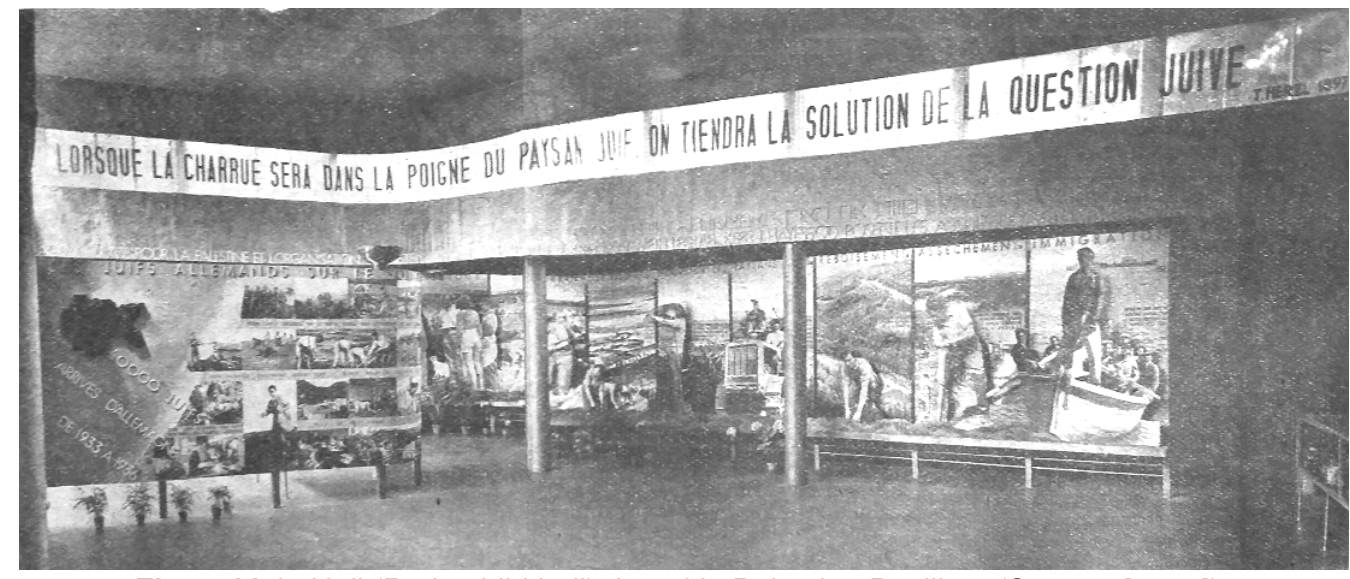

Fig. 4. Main Hall (Rothschild hall), Israel in Palestine Pavilion. (Source: [1: 24]).

The pavilion was unapologetically part of a wider political struggle for the legitimacy of the Zionist enterprise, a struggle that recruited the services of the print media. A special issue of the Palestine Hebrew newspaper Ha'aretz [30] was published especially for the exhibition, printed in both Hebrew and French, for distribution during the exhibition. This special edition ran a long comment on the Pavilion, stating: "Every exhibition means propaganda: for the fruit of the field, for the product of the anvil, for the achievement of science and technique, for the conquests of culture and art" [30: 2]. It added that "[t]he message of the land that is being built must be brought to these places of assembly, the propaganda to our building and our war, the fruits of our labor, our conquests and our tendencies". It concluded that "[t]he main theme of the pavilion is Palestine in its dynamism, the new man who creates a new land, and the land that renews Its youth to the person who comes to cultivates it" [30]. The pavilion was also featured, at length, in the June 1937 edition of the French Jewish magazine L'Univers Israélite. A photograph of the Pavilion adorned the front page, along with a quote from of Paul Bastid, the French minister of commerce, who praised the creativity of the Yishuv in saying that: "France does not ignore your magnificence in spirit, but your greatness in relation to human destiny is to live and create" [28: 1]. The achievements of the Yishuv were also celebrated by the French Zionist magazine La Terre Retrouvée, which provided its readers with a special illustrated catalogue of the Pavilion [1].

The pavilion was also a means to for the architects and urban planners of Palestine to engage the international architectural milieu. At the fourth RIA conference, which took place in Paris during the international exhibition, there was a Palestine delegate [31]; and those interested in the development of modern architecture in Palestine could obtain the "Palestine" issue of L'Architecture d'Aujourd'hui, which was distributed at the exhibition. The pavilion was also covered favourably by the French magazine $\mathrm{La}$ Construction Moderne, which reported that "[t]he pavilion of the Land of Israel at the Arts and Technoloav Exhibition aave a rather impressive idea of the development of 
Palestine. Thirty years later, the Jewish people returned to its land. It seems that the experiment was successful, according to the statistics and photomontages that cover the walls of the pavilion in accordance with the 1937 fashion" [32: 568].

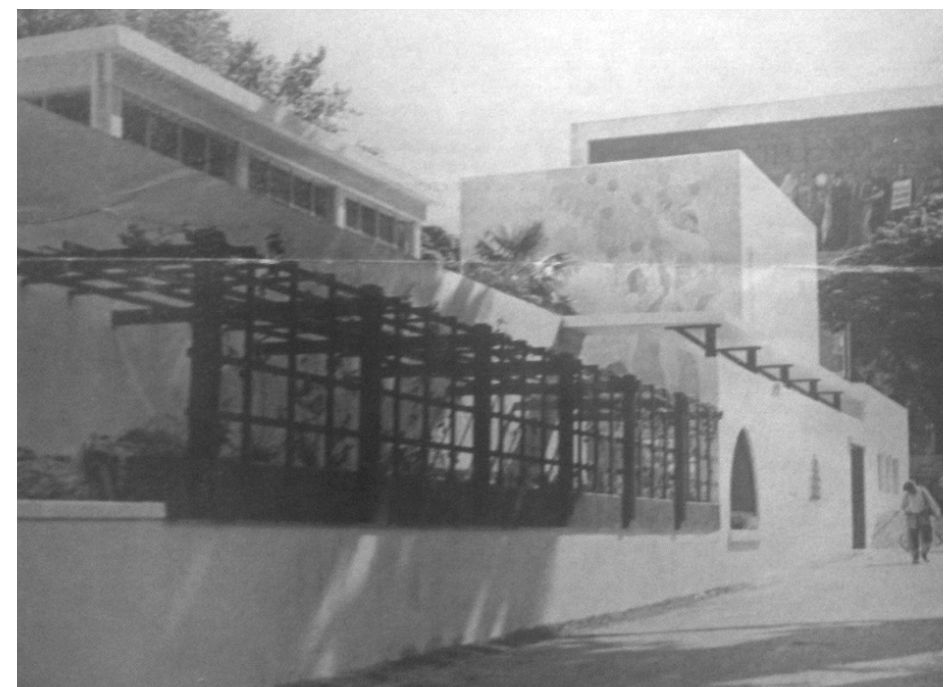

Fig. 5. Side façade of the Israel in Palestine Pavilion. (Source: [28: 1]).

The pavilion was a success and even won special awards. However, its principal objective, to disseminate the idea that the rural Jewish resettlements in Palestine were a solution to the "Jewish Question", did not succeed. A year after the exhibition, in 1938, the Jewish question was discussed at the Evian conference; the idea of resettlement of the Jews outside Europe was rejected by the participant countries. Again, at the New York World Fair of 1939, a last attempt was made to present the Jewish resettlement project as a solution to the Jewish plight. Housed in a thoroughly modern pavilion, the exhibition in New York also presented the achievements and triumphs of Jewish Palestine settlements [17]. But a mere five months after its opening in April of 1939, Germany invaded Poland and the migration of the Jews of Europe to become farmers in Palestine became, for a while, irrelevant.

\section{Conclusion}

The "Eretz Israel in Palestine" pavilion at the Paris International Exhibition of 1937 was part of a wider effort by the Zionist movement to put the Jewish farmer on display for an international audience. The architects and designers, urban planners and writers involved in this effort collaborated in cementing the image of the "New Jew", historically a native of the land while at the same time an innovative and creative modern man. The hybrid architecture and interior design of the 1937 pavilion, with its slogans and cutouts, was designed to give physical, if somewhat simplistic, form to this idea.

The idea that the image of the Zionist settlement should corresponded with the character of the Yishuv abroad turned architecture and architecture writings into tools for conveying the story of a society trying to define itself as part of the modern world, while at the same time finding and exhibiting its historical roots; a society which portrayed Jewish rural settlement as cure for anti-Semitic persecution. Though unable to solve the "Jewish question" through social reform or urban planning, the image of the Jewish farmer continued to serve as an important symbol for the Yishuv, and later for the state of Israel, 
for years to come. The nature of the character of the suited architectural representation would continue to preoccupy architects such as Harry Rosenthal, who wrote in 1945 : "the outstanding factor in the present building activity in Palestine is undoubtedly the strenuous endeavour of the Jews to settle down as a national community, and it is interesting to consider whether the architectural result is in any way expressive of the Jewish genius, whether it is characteristic of the country in which it is taking place, and whether it provides any contribution to the larger process of architectural evolution" [33].

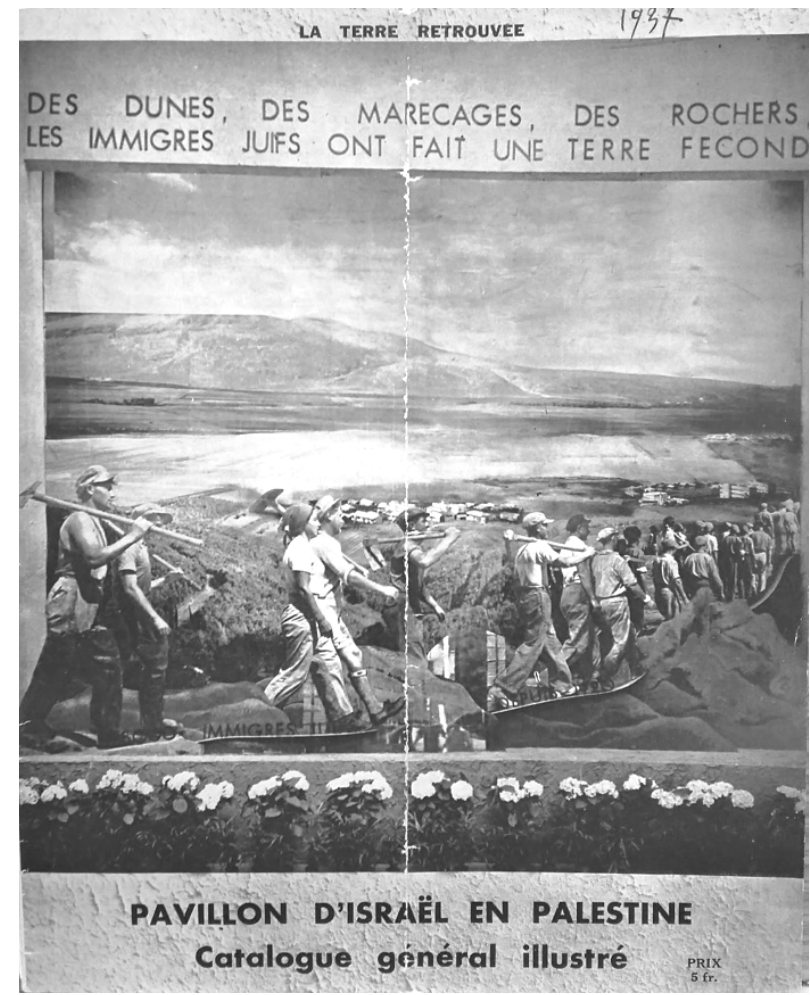

Fig. 6. A display Inside the Israel in Palestine on the front cover of [1].

\section{Brief Resume}

Tzafrir Fainholtz Is an architect, and an architecture historian. He holds a PhD from the Technion IIT (2015), where he is an adjunct lecturer and a scientific editor at the built heritage research center. He won many academic awards among them the "Le Corbusier Foundation scholarship" (2008). His research interests include the history and theory of modern architecture and heritage conservation. Recent publications include: 2017. "A Mediterranean Vienna: The Work of Viennese Architects and the Presence of Central European Culture in the Haifa of the 1930s and 1940s", The Leo Baeck Institute Year Book: 197-223.

\section{References}

1. "Pavillon d’Israël en Palestine Catalogue général illustré" (1937), La terre retrouvée, $\mathrm{n}^{\circ} 18-19,1$ July. 
2. SHAPIRA, A. 1982. "מיתוס היהודי החדש" [The myth of the New Jew], in J. Jolomb (ed.), ניטשה בתרבות העברית [The Nietzsche in Hebrew Culture], Jerusalem, Jerusalem, Hebrew University, Magness Press: 113-128.

3. CHYUTIN, M.; CHYUTIN, B. 2010. אדריכלות החברה האוטופית: קיבוץ ומושב : CHat [Architecture and Utopia - Kibbutz and Moshav], Jerusalem, Magnes press

4. KAHANA, F. 2011. לא עיר לא כפר-אדריכלות הקיבוץ, 1910-1990 [Neither Town nor Village - The Architecture of the Kibbutz, 1910-1990], Ramat-Gan, Yad-Tabenkin

5. LEVIN, M.; EPSTEIN-PLIOUCHTCH, M. (eds.), FAINHOLTZ, T. (ass. ed.) 2016. [יכארד קאופמן והפרויקט הציוני Aviv, Sifriat HaPoalim - Ha-Kibbutz Ha-Mehuhad.

6. NITZAN-SHIFTAN, A., EPSTEIN-PLIOUCHTCH, M.; ALON-MOZES, T. 2006. "Richard Kauffmann: Between Architectural and National Modernisms".

Docomomo Journal, $n^{\circ}$ 35: 48-54.

7. KAUFFMANN, R. 1926. "Judische Siedlungen in Palastina”, Städtebau, n 9-10: 149-158.

8. KAUFFMANN, R. 1926. "Planning of Jewish Settlements in Palestine", Town Planning Review, vol. 12, $\mathrm{n}^{\circ}$ 2: 93-116.

DOI: https://doi.org/10.3828/tpr.12.2.x7582tn8043g18ml

9. [“Colophon”] (1934). L'Architecture d'Aujourd'hui, vol. 5, nº 5 (June): 1.

Retrieved from:

https://portaildocumentaire.citedelarchitecture.fr/doc/IFD/FRAPN02_AA_1934_05 _PDF/l-architecture-d-aujourdhui-numero-5-1934 [available on 8 March 2019].

10. NITZAN-SHIFTAN, A. 1996. "Contested Zionism - Alternative modernism: Erich Mendelsohn and the Tel Aviv Chug in mandate Palestine", Architectural History, $n^{\circ} 39: 147-180$.

DOI: https://doi.org/10.2307/1568611

11. BARKAI, S ; POSENER, J. 1937. "Architecture en Palestine", L'Architecture d'Aujourd'hui, n' 9 (September): 2-34. Retrieved from:

https://portaildocumentaire.citedelarchitecture.fr/doc/IFD/FRAPN02_AA_1937_09 _PDF/l-architecture-d-aujourdhui-numero-9-1937 [available on 8 March 2019].

12. CANAAN, T. 1933. The Palestine Arab House: Its Architecture and Folklore. Jerusalem, Syrian Orphanage Press.

13. POSENER, J. 1938. "Traditionelles und modernes Bauen in Palästina." Das Werk, September: 257-271.

14. VOLAIT, M. 2011, "Une lignée d'architectes entre plusieurs mondes: les Fahmy d'Egypte", Cahiers de la Méditerranée [online], $\mathrm{n}^{\circ}$ 82. Retrieved from: http://journals.openedition.org/cdlm/5743 [available on 7 March 2019].

15. "La 3ème reunion internationale d'architectes: Compte-rendu officiel" (1935). L'Architecture d'Aujourd'hui, vol. 5, $\mathrm{n}^{\circ} 11$ (November): 8-26. Retrieved from: Retrieved from: https://portaildocumentaire.citedelarchitecture.fr/doc/IFD/FRAPN02_AA_1935_11 _PDF/l-architecture-d-aujourdhui-numero-11-1935 [available on 7 March 2019].

16. RATNER, E. 1935. "Rapport de M. Eugene Ratner", in Op. cit. [15]: 16-18.

17. KIRSHENBLATT-GIMBLETT, B. 2008. "Performing the State: The Jewish Palestine Pavilion at the New York World's Fair, 1939/40", in B. Kirshenblatt- 
Gimblett; J. Karp (eds.), The Art of Being Jewish in Modern Times, Philadelphia, University of Pennsylvania: 98-115.

DOI: https://doi.org/10.9783/9780812208863.98

18. DAVIDI, S. 2016. "יריד המזרח 1934: רוח הזמן ורוח המקום של תקופה ואנשיה [Levant Fair 1934: The Spirit of Time and the Spirit of Place of a Period and its People], [Atarim Magazine], n 6: 68.

19. "ביתן ארץ ישראלי בתערוכה הבין לאומית בפריז (The Palestine Pavilion at the

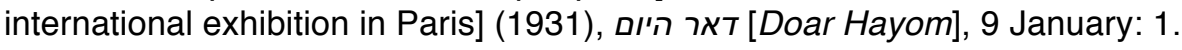

20. KEISARY, U. 1931. "בקור אחרון בתערוכה הקולוניאלית" [Last visit to the Colonial exhibition], דאר היום [Doar Hayom], 16 October: 4.

21. MORTON, P. 2000. Hybrid Modernities: Architecture and Representation at the 1931 Colonial Exposition, Cambridge, MIT Press.

22. ROBERTS N.-E. 2007. "Palestine on Display: The Palestine Pavilion at the British Empire Exhibition of 1924", The Arab Studies Journal, vol. 15, n 1: 70-89.

23. Menorah (1931). 29 May 1931: 1.

24. ROYER, J. (ed.) 1932. L'Urbanisme aux colonies et dans les pays tropicaux. Charité-sur-Loire, Dalayance.

25. KAUFFMANN, R. 1932. "Aménagement des colonies Juives en Palestine et principalement des colonies agricoles de l'organisation sioniste", in J. Royer (ed.), Op. cit. [24]: 224-238.

26. BORSI, F. 1987. The Monumental Era: European Architecture and Design, 19291939, London, Random House.

27. “Le pavillon d'Israël en Palestine" (1937), L'Architecture d'Aujourd'hui, n 9 (September): 45. Retrieved from:

https://portaildocumentaire.citedelarchitecture.fr/doc/IFD/FRAPN02_AA_1937_09 _PDF/l-architecture-d-aujourdhui-numero-9-1937 [available on 8 March 2019].

28. L'Univers Israélite (1937). 4 June.

29. "ביתן ארץ ישראל בתערוכה העולמית" [The Palestine pavilion at the world exhibition] (1937), דבר [Davar], 19 August: 4.

30. הארץ [Ha'aretz] (1937). 27 June.

31. "4è réunion internationale d'Architectes. Organisée sous le patronage de 'L'Architecture d'Aujourd'hui'. Programme" (1937). L'Architecture d'Aujourd'hui, vol. $8, n^{\circ} 8$ (August): 60 . Retrieved from:

https://portaildocumentaire.citedelarchitecture.fr/doc/IFD/FRAPN02_AA_1937_08 _PDF/l-architecture-d-aujourdhui-numero-8-1937 [available on 8 March 2019].

32. GILLE-DELAFON, S. 1938. "L'activité architecturale à Tel Aviv", La Construction moderne, vol. 53, $\mathrm{n}^{\circ} 35$ (4 September): 568-573. Retrieved from:

https://portaildocumentaire.citedelarchitecture.fr/doc/IFD/FRAPN02_COM_1938_ 035_PDF/la-construction-moderne [available on 8 March 2019].

33. ROSENTHAL, H. 1945. "Architecture in Palestine: the Jewish approach", The Crown Colonist, July: 485. 